\title{
Suppression of UVC-induced cell damage and enhancement of DNA repair by the fermented milk, Kefir
}

\author{
Tsutomu Nagira $^{1}$, Junko Narisawa ${ }^{1}$, Kiichirou Teruya ${ }^{1}$, Yoshinori Katakura ${ }^{1}$, Sun-Yup Shim ${ }^{1}$, \\ Ken-ichi Kusumoto ${ }^{3}$, Sennosuke Tokumaru ${ }^{2}$, Koichiro Tokumaru ${ }^{2}$, David W. Barnes ${ }^{3}$ \& \\ Sanetaka Shirahata ${ }^{1 *}$ \\ ${ }^{1}$ Department of Genetic Resources Technology, Faculty of Agriculture, Graduate School of Kyushu University, \\ Hakozaki, Higashi-ku, Fukuoka 812-8581, Japan; ${ }^{2}$ Nihon Kefir Co. Ltd., 13-15 Asahi-machi, Fujisawa 251-0054, \\ Japan: ${ }^{3}$ American Type Culture Collection, Manassas, VA 20110, U.S.A. \\ (* Author for correspondence; E-mail: shirahata@ grt.kyushu-u.ac.jp; Fax: +81 92642 3045)
}

Received 19 August 2002; accepted in revised form 10 October 2002

Key words: apoptosis, DNA repair, Kefir, reactive oxygen species (ROS), thymine dimer, unscheduled DNA synthesis (UDS), UV damage

\begin{abstract}
An aqueous extract of Kefir, fermented milk originally produced in the Caucasus mountains, suppressed morphological changes of human melanoma HMV-1 and SK-MEL cells and human normal fibroblast TIG-1 cells caused by UVC-irradiation, suggesting that UV damage can be suppressed by the Kefir extract. The addition of the Kefir extract after UVC-irradiation of HVM-1 cells resulted in a remarkable decrease in intracellular reactive oxygen species (ROS) which had been increased by UVC irradiation. The Kefir extract also stimulated unscheduled DNA synthesis and suppressed UVC-induced apoptosis of HMV-1 cells. A colony formation assay revealed that the Kefir extract rescued HMV-1 cells from cell death caused by UVC irradiation. The Kefir extract, as well as methyl methanethiosulfonate which is known to enhance the nucleotide excision repair (NER) activity, exhibited strong thymine dimer repair-enhancing activity. Epigalocatechin exhibited a weak NER activity but vitamins A, C, and E and catechin showed no NER activity. The thymine dimer repair-enhancing factors in the Kefir extract were heatstable and assumed to be molecules with a molecular weight of less than 5000. The treatment of HMV-1 cells with the Kefir extract during or before UVC- irradiation also prevented the generation of ROS and thymine dimmer, and suppressed the apoptosis of HMV-1 cells, suggesting that application of Kefir can prevent UV damage.
\end{abstract}

Abbreviations: BrdU, bromodeoxyuridine; DCFH-DA, 2',7'-dichlorofluorescin-diacetate; DSB, double strand break; FBS, fetal bovine serum; HBSS, Hanks' balanced salt solution; MMTS, methyl methanethiosufonate; NER, nucleotide excision repair; ROS, reactive oxygen species; UDS, unscheduled DNA synthesis; UV, ultraviolet ray.

\section{Introduction}

Ultraviolet ray (UV) is categorized into three regions, UVA, UVB and UVC. UVA has a wavelength range from $320-400 \mathrm{~nm}$ and forms about $90 \%$ of solar ultraviolet radiation. UVB has a wavelength range of 290-320 nm, and forms about $10 \%$ of solar ultraviolet radiation. UVC is in the $190-290 \mathrm{~nm}$ wavelength region. UVA generates reactive oxygen species (ROS) such as ${ }^{1} \mathrm{O}_{2}, \mathrm{O}_{2}^{-}, \mathrm{H}_{2} \mathrm{O}_{2}$ and $\cdot \mathrm{OH}$, which cause ox- idative DNA damage (Fu et al., 2000). ROS cause structural alterations in the chromosomal DNA such as base pair mutations, rearrangement, and deletions (Wiseman et al., 1994). Unrepaired oxidative DNA damage results in genetic mutation, cell death or cellular carcinogenesis. ROS can also modulate the activity of proteins and genes that respond to stress, and regulate the genes that are related to cell proliferation, differentiation, and apoptosis. The base excision repair (BER) system recognizes and repairs oxidative dam- 
aged chromosomal DNA (Nyaga and Lloyd, 2000; Garcia et al., 2000; Mitra et al., 2001).

UVB directly produces several kinds of photoproducts in DNA in addition to indirect oxidative DNA damage (Ravanat et al., 2001). The major photoproducts in DNA induced by UV are pyrimidine dimers, especially thymine dimmers (You et al., 2001). Pyrimidine dimers are generated by a photochemical cycloaddition between adjacent pyrimidines, leading to covalently linked bases and altered DNA conformation. This structural change is recognized by cellular enzymes and is corrected via the nucleotide excision repair (NER) pathway (Cleaver and Crowley, 2002). NER is the repair-system that removes a wide range of DNA-damage including UV-induced thymine dimers and modification induced by chemical substances. Defects in the NER system can result in skin cancer (Venema et al., 1991; Sancar et al., 1996).

UVC acts on biological systems in basically the same manner as UVA and UVB, but UVC causes more serious damage because the light's energy is greater (Petitfrere et al., 1996; Heo et al., 2001). Since UVC is blocked by the ozone layer, it does not usually reach the earth's surface. However, ongoing environmental pollution, the appearance of a large ozone hole above the South Pole, and the thinning ozone layer above Australia and New Zealand have resulted in increased UV damage by UVB or even by UVC, which might increase the incidence of skin cancer.

DNA damage induced by UV-irradiation is repaired by the DNA repair systems. The $\mathrm{p} 53$ pathway recognizes DNA damage, chromosomal aberration, and DNA breakage, inducing the G1 arrest to enhance DNA repair. However, on severe DNA damage, it triggers apoptosis to prevent the proliferation of DNAdamaged cells (Amundson et al., 1998). Mutations that are not repaired by the DNA-repair systems or removed by apoptosis, permanently alter DNA to induce cancer or many other diseases.

The search for DNA repair enhancing factors and ROS scavenging factors is important for finding agents that can suppress cancer or other diseases. It is known that various types of inhibitors that act against mutagens and carcinogens exist in our daily food, and are believed to have important roles in reducing the risk of mutagenesis and carcinogenesis in humans. Two main chemical groups of inhibitors against various mutagens, desmutagens and bio-antimutagens, have been identified based on their mode of action (Kada et al., 1987). Desmutagens are substances that directly deactivate mutagens before they damage DNA. Bio- antimutagens are substances that reduce mutation by enhancing DNA-repair activity or by inhibiting DNA replication in DNA-damaged cells.

DNA-repair enhancing factors in foods would be beneficial in preventing cancer and many other diseases. However, only a few substances have been reported to have this ability, including S-methyl methanethiosufonate (MMTS) from cauliflower (Nakamura et al., 1996, 1998), epigallocatechin (Shimoi et al., 1986) and gallocatechin (Matsuo et al., 1994). Kefir is a fermented milk drink, originally produced in the Caucasus Mountains, that is known to have numerous benefits including an anti-cancer effect (Shiomi et al., 1982; Kubo et al., 1992), an immunopotentiative effect (Murofushi et al., 1986; Osada et al., 1994; Thoreux and Schmucker, 2001), an anti-stress effect (Kabayama et al., 1997), an anti-diabetes effect (Teruya et al., in press) and a probiotics/prebiotics effect (Zubillaga et al., 2001). Kefir contains unique products derived from a very complex fermentation process with more than 30 kinds of lactic acid bacteria, acetic acid bacteria and yeasts agglutinated with polysaccharides. Many polysaccharides isolated from fungi, lichen, yeast and bacteria are known to have inhibitory effects on tumor growth (Murofushi et al., 1986; Pool-Zobel et al., 1993).

Here we report that the Kefir aqueous extract contains active substances that can efficiently scavenge UVC-induced intracellular ROS, stimulate thymine dimer repair and rescue UV-damaged cells from apoptosis.

\section{Materials and methods}

\section{Reagent}

Vitamin C (ascorbic acid) (Wako Pure Chemicals, Tokyo), (+)-catechin (Sigma, St. Louis, MO, U.S.A.), and (-)-epigallocatechin (Sigma, St. Louis, MO, U.S.A.) were dissolved in a phosphated buffered saline (PBS) solution and diluted in F12 medium immediately before use. Vitamin A (retinal) (Wako Pure Chemicals, Tokyo), vitamin E ( $\alpha$-tocopherol) (Wako Pure Chemicals, Tokyo), vitamin $\mathrm{K}_{3}$ (2-methyl-1, 4naphthoquinone), and MMTS (Sigma, St. Louis, MO, U.S.A.) were dissolved in ethanol and diluted in F12 medium before use. 
Cells and cell culture

A human melanoma cell line HMV-1 was provided by the RIKEN Cell Bank (HeLa contamination was indicated by RIKEN). Human normal fibroblast TIG- 1 cells and human melanoma SK-MEL cells were obtained from the Japan Cell Resources Bank (JCRB). HMV-1 and SK-MEL cells were cultured in Ham's F12 medium (Nissui, Tokyo) supplemented with $10 \%$ fetal bovine serum (FBS) under an atmosphere of $5 \% \mathrm{CO}_{2}$ at $37{ }^{\circ} \mathrm{C}$. TIG- 1 cells were cultured in Ham's MEM medium (Nissui, Tokyo) supplemented with $10 \%$ FBS under an atmosphere of $5 \% \mathrm{CO}_{2}$ at $37^{\circ} \mathrm{C}$.

\section{Preparation of the Kefran-Kefir aqueous extract}

Four grams of Kefram-Kefir ${ }^{\mathrm{TM}}$ powder, supplied by Nihon Kefir Co. Ltd., Fujisawa, Japan, was dissolved in $20 \mathrm{ml}$ ultra pure water and centrifuged at $12000 \mathrm{rpm}$ for $2 \mathrm{~h}$ to remove the insoluble fraction. The supernatant fluid was filtered with a $0.2 \mu \mathrm{m}$ filter and used as the Kefram-Kefir aqueous extract sample. The weight of solutes in the sample was determined after lyophilization. The aqueous extract was diluted in F12 medium supplemented with $10 \%$ FBS to give a final concentration of $9.6 \mathrm{mg} \mathrm{ml}^{-1}$. The Kefir aqueous extract $\left(13.9 \mathrm{mg} \mathrm{ml}^{-1}\right)$ was fractionated in two fractions (>5000 and $<5000$ molecular weight) using a Sephadex G-25 column (NAP-5 column, Pharmacia).

\section{UVC-irradiation}

The source of UVC was a National $15 \mathrm{~W}$ germicidal lamp (National GL-15) capable of delivering radiation at a wavelength of $254 \mathrm{~nm}$. The distance from the cells to the source was $30 \mathrm{~cm}$. The energy of the UV irradiation was determined by a UV intensity meter.

\section{Detection of the redox state in cultured animal cells}

HMV- 1 cells $\left(5.0 \times 10^{5}\right.$ cells $)$ were seeded in a $35 \mathrm{~mm}$ culture dish and cultivated overnight. The cells were then UV-irradiated at $60 \mathrm{~J} \mathrm{~m}^{-2}$, washed with PBS and incubated with the Kefir extract in a fresh medium for 5-10 min. After washing twice with Hanks' Balanced Salt Solution (HBSS), the cells were incubated with $0.25 \mu \mathrm{M} \mathrm{2}$, $7^{\prime}$-dichlorofluorescin-diacetate (DCFHDA) in HBSS for $3 \mathrm{~min}$ at room temperature. After washing twice with HBSS, fluorescence images were observed using con-focal laser scanning microscopy (Molecular dynamics, U.S.A.) (Shen et al., 1996).
Measurement of unscheduled DNA synthesis (UDS)

A cell-proliferation assay (Amersham Pharmacia Biotech, Buckinghamshire, England) was used to measure unscheduled DNA synthesis (UDS) (Anna et al., 1994). UDS was detected by measuring the incorporation of bromodeoxyuridine (BrdU) in the DNA using a peroxidase-labeled anti-BrdU specific antibody. HMV- 1 cells $\left(2 \times 10^{4}\right.$ cells $)$ were seeded in 96 well microtiter plates and cultured overnight in Ham's MEM medium supplemented with $10 \%$ FBS. To measure UDS, HMV-1 cells were cultured in the medium containing no thymidine. Cells were UVirradiated with $15 \mathrm{~J} \mathrm{~m}^{-2}$, washed with PBS, and incubated for $1-24 \mathrm{~h}$ in a fresh $100 \mu \mathrm{l}$ labeling medium containing $10 \mu \mathrm{m} \mathrm{BrdU}$ and the Kefir extract. The cells were treated with $50 \mathrm{mM}$ hydroxyurea (Wako, Tokyo) to minimize replication of DNA as a result of cell division. After removing the labeling medium, the cells were treated for $30 \mathrm{~min}$ with a fixative solution at room temperature. After removing the fixative solution, cells were incubated for $30 \mathrm{~min}$ at room temperature in a blocking buffer $(50 \mathrm{mM}$ Tris- $\mathrm{HCl} ; 50 \mathrm{mM}$ $\mathrm{NaCl}, \mathrm{pH} 7.4$ ), which contained $1 \%$ protein. After removing the blocking buffer, the cells were incubated in a peroxidase-labeled anti-BrdU working solution for $2.5 \mathrm{~h}$ at room temperature. Following the removal of this working solution, cells were washed three times with a washing solution. The cells were then incubated for $30 \mathrm{~min}$ at room temperature with $3,3^{\prime}, 5$, $5^{\prime}$-tetramethylbenzidine (TMB) substrate. The coloring reactions were determined by an ELISA reader at $450 \mathrm{~nm}$ after adding $25 \mu \mathrm{l}$ of $1 \mathrm{M} \mathrm{H}_{2} \mathrm{SO}_{4} /$ well. The enhanced UDS rate was evaluated as a percentage of the increment of the color values measured 1-24 h after UV-irradiation against the value for the control cells with no UV-irradiation.

\section{Detection of apoptosis}

To detect apoptosis we used an apoptosis detection system, fluorescence kit (Promega, Madison, WI, U.S.A.). Apoptotic cells were detected by the TUNEL (terminal deoxynucleotidyltransferasemediated, dUTP-incorporated nick end labeling) method, which detects the $3^{\prime}-\mathrm{OH}$ end of chromosomal DNA breakage generated by apoptosis (Gavrieli et al., 1992). HMV-1 $\left(2 \times 10^{5}\right.$ cells $)$ cells were seeded on chamber slides (Nunc, Tokyo) and cultured overnight in F12 medium supplemented with $10 \%$ FBS. Cells were UV-irradiated with $60 \mathrm{~J} \mathrm{~m}^{-2}$, washed with PBS, 

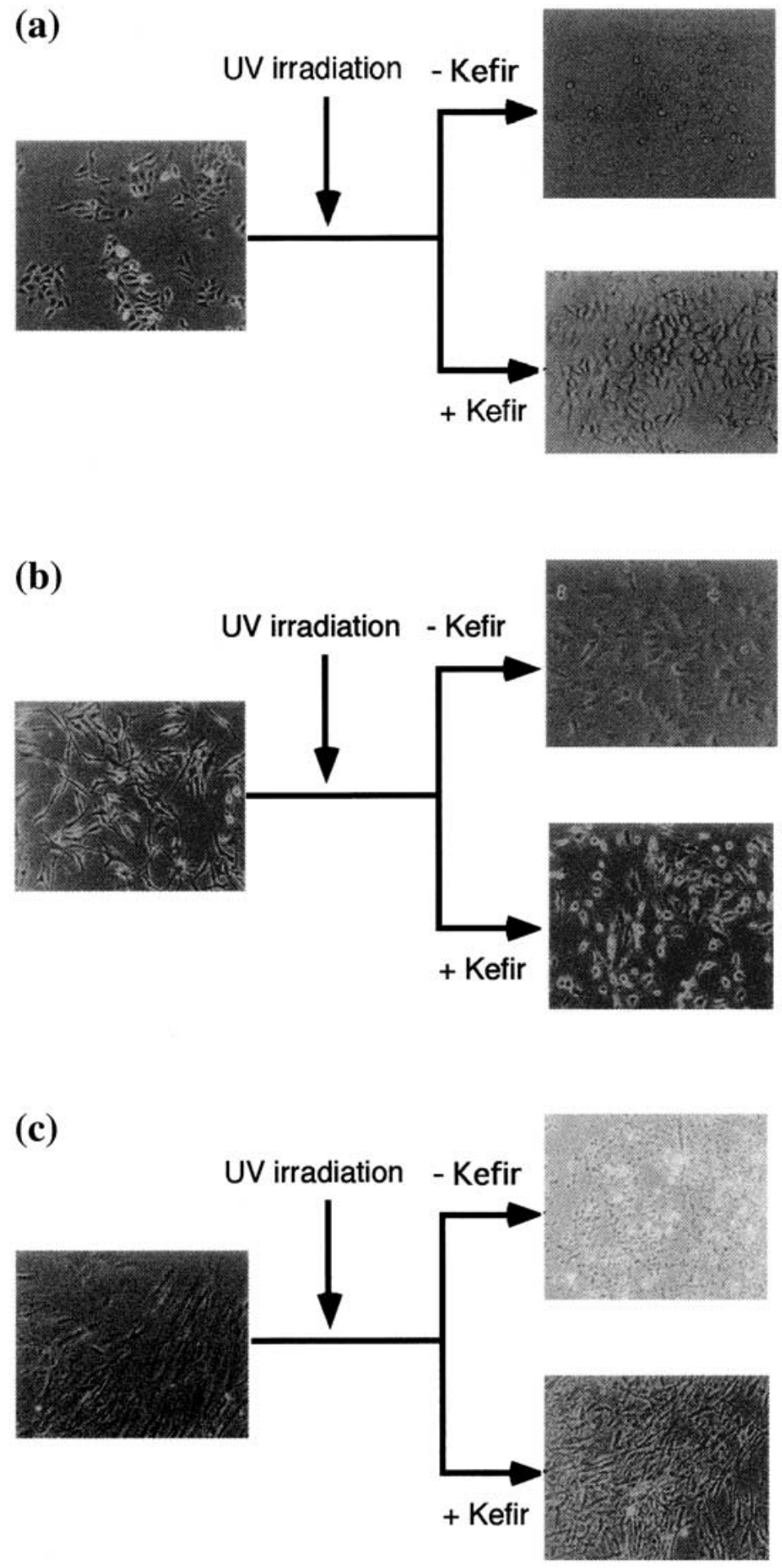

Figure 1. Suppressive effect of the Kefir extract on UVC-induced morphological changes of human melanoma HMV-1 cells and SK-MEL cells and human normal fibroblast TIG-1 cells. (a) HMV-1 cells $\left(1.0 \times 10^{6}\right.$ cells) UV-irradiated with $60 \mathrm{~J} \mathrm{~m}^{-2}$ and incubated with the Kefir extract $\left(9.6 \mathrm{mg} \mathrm{ml}^{-1}\right)$ for $5 \mathrm{~h}$. (b) SK-MEL cells $\left(1 \times 10^{6}\right.$ cells) irradiated with $60 \mathrm{~J} \mathrm{~m}^{-2}$ and incubated with the Kefir extract $\left(19.2 \mathrm{mg} \mathrm{ml}^{-1}\right)$ for $48 \mathrm{~h}$. (c) TIG-1 cells $\left(1.0 \times 10^{6}\right.$ cells) UV-irradiated with $60 \mathrm{~J} \mathrm{~m}^{-2}$ and incubated with the Kefir extract $\left(19.2 \mathrm{mg} \mathrm{ml}^{-1}\right)$ for $48 \mathrm{~h}$. All experiments were triplicated independently and a representative is shown. 
and incubated for $5 \mathrm{~h}$ in a culture medium containing the Kefir extract. The cells were then fixed with $4 \%$ formalin overnight at $4^{\circ} \mathrm{C}$. The cells were washed twice for 5 min with PBS and blocked with $0.2 \%$ TritonX-100/PBS for $5 \mathrm{~min}$ on ice. The cells were then pretreated for $5 \mathrm{~min}$ with an equilibration buffer. After removing the equilibration buffer, the cells were incubated in a reactive buffer (equilibration buffer, Nucleotide Mix and terminal deoxynucleotidyl transferase (TdT) enzyme) at room temperature for $70 \mathrm{~min}$. The cells were then exposed to $2 \times \mathrm{SSC}$ at room temperature for $15 \mathrm{~min}$. After removing the $2 \times \mathrm{SSC}$, the cells were washed twice with PBS. Images were captured using con-focal laser scanning microscopy (excitation at $513 \mathrm{~nm}$, emission at $535 \mathrm{~nm}$ ) (Molecular Dynamics, U.S.A.).

\section{Detection of the colony forming ability}

HMV-1 cells were seeded in a $60 \mathrm{~mm}$ culture dish and cultured overnight. The cells were then UV-irradiated with $4.6,6.9,6.9,9.2,11.5$, and $13.8 \mathrm{~J} \mathrm{~m}^{-2}$ and washed with PBS. The cells were incubated for $5 \mathrm{~h}$ in a culture medium containing the Kefir extract. The cells $\left(1 \times 10^{3}\right.$ cells $)$ were then seeded in a 24 well microtiter plate and cultured in fresh medium for 1 week. After washing with PBS, the cells were fixed with methanol for $5 \mathrm{~min}$. After removing the methanol, the cells were air-dried and stained with Giemsa solution for $10 \mathrm{~min}$. After removing the Giemsa solution, the cells were washed with distilled water and air-dried. The number of colonies were counted and the colony formation ratio was calculated as a percentage of the control (Kasten et al., 1995, 1997).

\section{Detection of thymine dimer}

HMV- 1 cells $\left(2.0 \times 10^{5}\right.$ cells $)$ were seeded on chamber slides (Nunc, Tokyo) and cultured overnight in F12 medium supplemented with 10\% FBS. Cells were UV-irradiated with $60 \mathrm{~J} \mathrm{~m}^{-2}$, washed with PBS and incubated in fresh medium with the Kefir extract for 2-4 h. The cells were then fixed overnight with $4 \%$ formalin. The cells were washed twice with PBS and blocked for $2 \mathrm{~h}$ with $0.1 \%$ TritonX-100/3\% FBS/PBS. Next, the cells were incubated for $2 \mathrm{~h}$ at room temperature with a $1 / 100$ dilution of the mouse monoclonal antibody anti-thymine dimer (KYOWA, Tokyo) in $0.1 \%$ TritonX-100/3\% FBS/PBS (Koji et al., 1990; Razzaque et al., 1994). The cells were washed twice with PBS and incubated for $2 \mathrm{~h}$ at room temperature in the dark with a 1/200 dilution of affinity-isolated

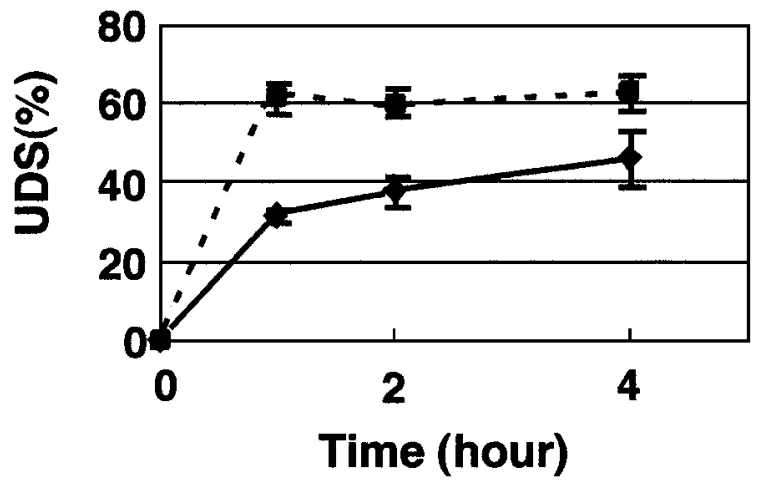

Figure 2. Enhancement of UDS by the Kefir extract. HMV-1 cells $\left(2.0 \times 10^{4}\right.$ cells/well) were UV-irradiated with $15 \mathrm{~J} \mathrm{~m}^{-2}$ in a 96-well microplate and incubated with BrdU and the Kefir extract ( $9.6 \mathrm{mg} \mathrm{ml}^{-1}$ ) for 1-24 h. UDS was determined by using the immunoblot assay. All experiments were triplicated independently and the standard error bars were shown in the figure.

goat anti- (mouse immunoglobulins) gamma and light chains human IgG absorbed fluorescein conjugate (BIOSOURCE) in $0.1 \%$ TritonX-100/3\% FBS/PBS. After washing three times with PBS, images were captured using a fluorescence microscope (OLYMPUS, Tokyo).

\section{Results}

Suppressive effect of the Kefir extract on morphological changes of animal cells caused by UVC irradiation

UVC-irradiation causes morphological changes and apoptosis in animal cells. As shown in Figure 1, human melanoma HMV-1 and SK-MEL cells and human normal fibroblast TIG-1 cells were all morphologically changed $5 \mathrm{~h}$ after UV-irradiation. However, the addition of the Kefir extract after UVC-irradiation significantly reduced these morphological changes, suggesting that the Kefir extract contains active substances which could protect cells from UV damage.

\section{Scavenging effect of the Kefir extract on} $U V C$-induced intracellular ROS

DCFH-DA is commonly used to detect intracellular ROS, especially accumulated intracellular hydrogen peroxide. UVC-irradiation generated a remarkable amount of ROS in HMV-1 cells (data not shown). The level of intracellular ROS rose considerably immediately after UVC irradiation and then decreased to 


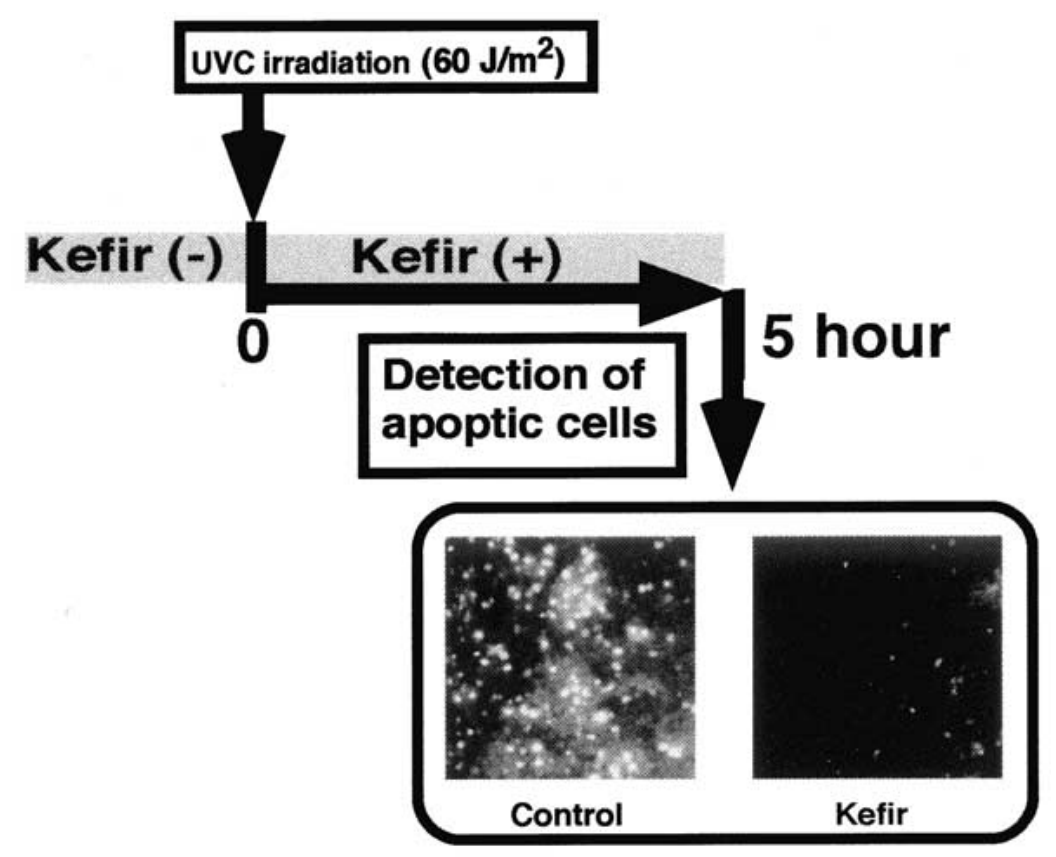

Figure 3. Suppression of UV irradiation-induced apoptosis in HMV-1 cells by the Kefir extract $\left(9.6 \mathrm{mg} \mathrm{ml}^{-1}\right) . \mathrm{HMV}^{-1} \mathrm{cells}\left(2.0 \times 10^{5}\right.$ cells $)$ were UV-irradiated with $60 \mathrm{~J} \mathrm{~m}^{-2}$ and incubated with the Kefir extract for $5 \mathrm{~h}$. Apoptotic cells were detected using immunoblot assays. All experiments were triplicated independently and a representative is shown.

$60 \%$ after $5 \mathrm{~min}$. However, the high oxidative state was maintained even after $10 \mathrm{~min}$. On the other hand, the addition of the Kefir extract after UVC irradiation resulted in a rapid reduction of the level of intracellular ROS to $20 \%$ after $5 \mathrm{~min}$ and to approximately $0 \%$ after $10 \mathrm{~min}$, the level before UVC irradiation. These result suggest that the Kefir extract contains potent antioxidants which effectively scavenge intracellular ROS.

\section{Enhancement of UDS by the Kefir extract}

Scheduled DNA synthesis designates normal replication of DNA for cell division whereas UDS reflects DNA synthesis for repair of damaged DNA. After UVC irradiation, UDS was enhanced in HMV-1 cells time-dependently by 32,38 and $45 \%, 1,2$ and $4 \mathrm{~h}$ after UVC-irradiation, respectively (Figure 2). UDS in HMV-1 cells which were treated with the Kefir extract after UVC irradiation was enhanced by 62,60 and $62 \%, 1,2$ and $4 \mathrm{~h}$ after UVC-irradiation, respectively. These results suggest that the Kefir extract contains DNA repair enhancing substances.

\section{Suppression of apoptosis by the Kefir extract}

Since UVC-irradiated cells undergo apoptosis we examined the ability of the Kefir extract to rescue UVCirradiated cells from apoptosis. Apoptosis was identified by the TUNNEL method in which $3^{\prime}-\mathrm{OH}$ terminals of fragmented DNA were detected. As shown in Figure 3, apoptosis of the UVC-irradiated HMV-1 cells was drastically suppressed after $5 \mathrm{~h}$ by the addition of the Kefir extract. The suppressive effect of the Kefir extract was observed dose-dependently in a concentration of more than $900 \mu \mathrm{g} \mathrm{ml}^{-1}$.

\section{Enhanced colony formation of UVC-damaged HMV-1} cells by the Kefir extract

UV damage causes growth inhibition and apoptosis in animal cells. In order to examine if the Kefir extract can completely rescue animal cells from UV-induced cell death, the effect of the Kefir extract on the colony formation ability of UV-irradiated HMV-1 cells was examined. As shown in Figure 4, the colony formation ratio for HMV-1 cells decreased depending upon the intensity of UVC-irradiation. However, the addition of the Kefir extract after UVC-irradiation, significantly increased the colony formation ratio to $11 \%$, whereas for the non-treated cells it was $0.14 \%$ when UVC 


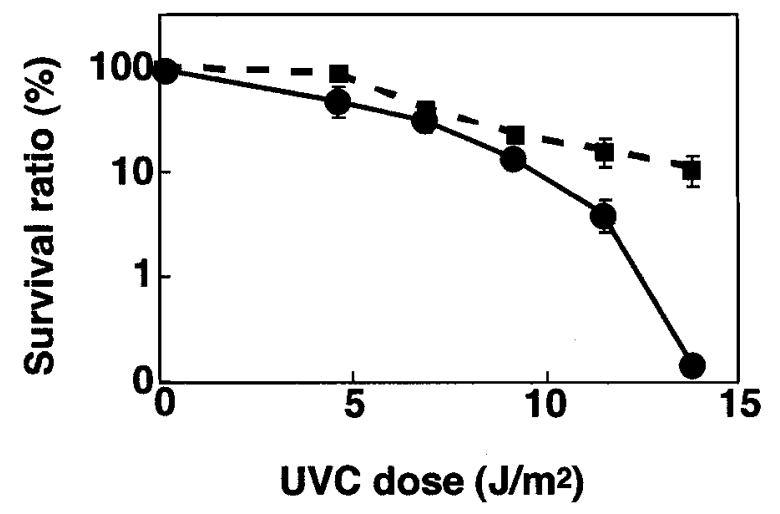

Figure 4. Enhanced colony formation of UV-damaged HMV-1 cells using the Kefir extract. HMV-1 cells $\left(5.0 \times 10^{5}\right.$ cells $)$ were UV-irradiated with $4.6,6.9,6.9,9.2,11.5,13.8 \mathrm{~J} \mathrm{~m}^{-2}$ and then incubated with the Kefir extract $\left(9.6 \mathrm{mg} \mathrm{ml}^{-1}\right)$ for $5 \mathrm{~h}$. The UV-irradiated cells were seeded at $1.0 \times 10^{3}$ cells in each well of a 24 well microtiter plate and cultured for 1 week. Solid line, control; broken line, the treatment with the Kefir extract. All experiments were triplicated independently. The standard error bars are shown in the figure.

of $13.8 \mathrm{~J} \mathrm{~m}^{-2}$ was irradiated. These results demonstrate that HMV-1 cells rescued from UVC-induced apoptosis proliferate to form colonies.

\section{Enhancement of the thymine dimer excision repair pathway by the Kefir extract}

The rapid increase of UDS by treatment with the Kefir extract suggests that the NER system in UVCirradiated HMV-1 cells was enhanced by the Kefir extract. UVC-irradiation generates thymine dimers in DNA. We examined the effect of the Kefir extract on the UVC-induced thymine dimer formation, which is the main cause of cell death by UVC irradiation. Thymine dimers were detected by immunostaining using an anti-thymine dimer antibody. As shown in Figure 5, a number of thymine dimers were formed in HMV-1 cells upon UVC irradiation and this number did not decrease significantly after 2 and $4 \mathrm{~h}$. However, the addition of the Kefir extract after UVC irradiation resulted in a remarkable decrease in the number of thymine dimers, suggesting that the Kefir extract contains active substances which enhance the thymine dimer excision repair pathway.

We compared the effect of the Kefir extract on the UVC-induced thymine dimer formation to those of other antioxidants (vitamin A, C, E, K, catechin, and epigallocatechin) and MMTS that are known to enhance DNA repair activity (Table 1). The Kefir extract dose-dependently stimulated thymine dimer excision
Table 1. Effects of various antioxidants and the Kefir extract on the thymine dimer repair in the UVC-irradiated HMV-1 cells

\begin{tabular}{lrc}
\hline Antioxidants & $\begin{array}{c}\text { Concentration } \\
\left(\mu \mathrm{g} \mathrm{ml}^{-1}\right)\end{array}$ & $\begin{array}{c}\text { Stimulation of } \\
\text { thymine dimer repair }\end{array}$ \\
\hline Vitamin A & 10 & \pm \\
Vitamin C & 500 & \pm \\
Vitamin E & 1 & \pm \\
Vitamin K & 1 & \pm \\
Catechin & 14500 & \pm \\
Epigallocatechin & 15300 & + \\
Methyl methane & 10 & +++ \\
thiosulfonate & & ++ \\
Kefir extract & 21000 & +++ \\
& 14000 & +++ \\
& 7000 & +++ \\
& 3500 & +++ \\
& 1800 & + \\
& 900 & \pm \\
& 450 & \pm \\
& 0 & + \\
& & + \\
& & + \\
& & +
\end{tabular}

HMV-1 cells were irradiated with UVC $\left(60 \mathrm{~J} \mathrm{~m}^{-2}\right)$ and formed thymine dimers were detected by immunostain using anti-thymine dimer antibody. The suppressive effects of various antioxidants and the Kefir extract on the formation of thymine dimers were evaluated by measuring the fluorescence intensity using a confocal microscope.

\pm , Less than $10 \%$ of suppressive effect;,$+ 10-30 \%$ of suppressive effect;,$++ 30-50 \%$ of suppressive effect; +++ , more than $50 \%$ of suppressive effect.

repair in UVC-irradiated HMV-1 cells in a concentration of more than $900 \mu \mathrm{g} \mathrm{ml}^{-1}$ as well as MMTS, whereas, epigallocatechin exhibited a weak enhancing effect at $15300 \mu \mathrm{g} \mathrm{ml}^{-1}$. However, Vitamins A, C, E, and K (Vervoort et al., 1997; Rhodes et al., 2000) and catechin did not exhibit detectable thymine dimmer repair-enhancing activity in the concentrations at which their anti-oxidative effects were expected from references, suggesting that anti-oxidative activity is not necessarily related to the DNA repair-enhancing activity.

To characterize DNA repair-enhancing substances in the Kefir extract, two fractions with molecular weights of more than 5000 and less than 5000 were tested (Table 2). The thymine dimmer repairenhancing activity of the Kefir extract was detected in the fraction of molecular weight of less than 5000 . The active substances in the fraction were heat stable, as demonstrated by the fact that the thymine dimer repair-enhancing activity was not lost by autoclaving. 


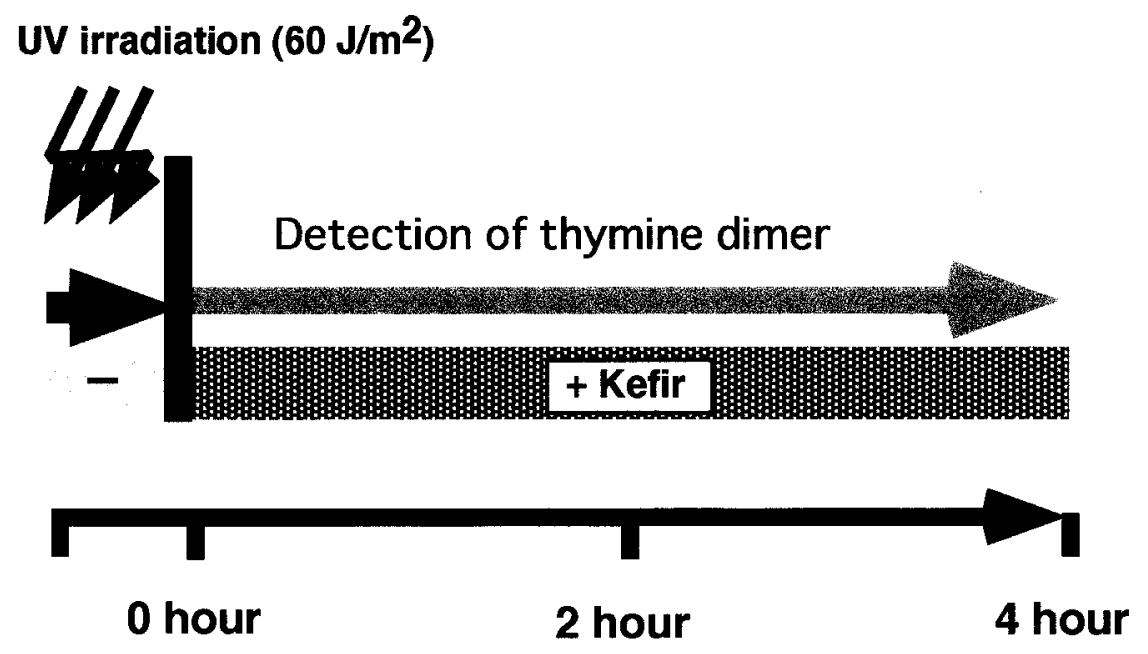

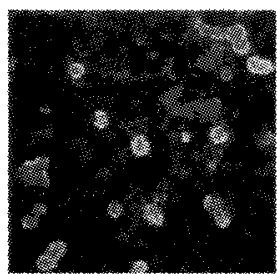

Control

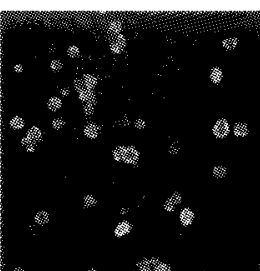

Control

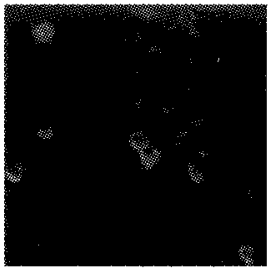

Kefir

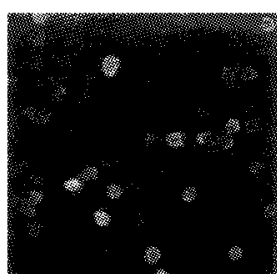

Control

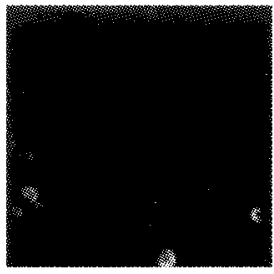

Kefir

Figure 5. Enhancing effect of the thymine dimer excision repair pathway by the Kefir extract. HMV- 1 cells $\left(2.0 \times 10^{5}\right.$ cells $)$ were UV-irradiated with $60 \mathrm{~J} \mathrm{~m}^{-2}$ and incubated with the Kefir extract $\left(9.6 \mathrm{mg} \mathrm{ml}^{-1}\right)$ for $2-4 \mathrm{~h}$. Thymine dimers were detected by immunoblot assays. All experiments were triplicated independently and a representative is shown.

Suppression of UVC damage in HMV-1 cells by the addition of the Kefir extract during UVC irradiation

UV-cut cosmetics are known to contain UV-absorbing materials which protect the skin from UV damage. In order to examine if the Kefir extract has a similar effect, HMV-1 cells were treated with the Kefir extract only during UVC-irradiation. The intracellular ROS in untreated cells increased significantly with UVC irradiation. However, treatment of HMV-1 cells with the
Kefir extract for 1 min during UVC-irradiation resulted in a remarkable suppression of intracellular ROS generation (data not shown). The redox state of the HMV-1 cells treated with the Kefir extract shifted to a more reduced state than that of the control cells, even after UVC-irradiation. This suggests that the Kefir extract can scavenge intracellular ROS generated by the normal respiration activity of cells. Thymine dimer formation in HMV-1 cells treated with the Kefir extract 
Table 2. Characterization of active substances in the Kefir extract on the thymine dimer repair in UV-irradiated HMV-1 cells

\begin{tabular}{lc}
\hline Sample & $\begin{array}{c}\text { Stimulation of } \\
\text { thymine dimer repair }\end{array}$ \\
\hline Kefir extract & +++ \\
Kefir extract with M.W. ${ }^{\text {a }}$ of more than 5000 & \pm \\
Kefir extract with M.W. of less than 5000 & +++ \\
Autoclaved Kefir extract & +++ \\
Autoclaved Kefir extract with M.W. of more than 5000 & \pm \\
Autoclaved Kefir extract with M.W. of less than 5000 & +++ \\
\hline
\end{tabular}

The Kefir extract $\left(13.9 \mathrm{mg} \mathrm{ml}^{-1}\right.$ ) was gel-filtrated using a Sephadex G-25 column and two fractions with molecular weights of more than 6000 and less than 5000 were obtained. The Kefir extract and the gel-filtrated fractions were autoclaved. The meaning of \pm and +++ was described in the legend of Table 1 .

${ }^{\mathrm{a}}$ M.W. = molecular weight.

during UVC-irradiation was considerably reduced $5 \mathrm{~h}$ after UVC-irradiation, compared to the control (Figure 6a). The apoptosis of HMV-1 cells treated with the Kefir extract during UV-irradiation was also suppressed $5 \mathrm{~h}$ after UV-irradiation (Figure 6b). Since the Kefir extract exhibited UV absorption of which the peak was at $280 \mathrm{~nm}$ (data not shown), the protective effect of the Kefir extract from UV damage may be attributed to its UV absorption effect.

Next, HMV-1 cells were pretreated with the Kefir extract for $5 \mathrm{~h}$ before the UVC-irradiation. Pretreatment of HMV-1 cells with the Kefir extract before UVC-irradiation resulted in a notable suppression of intracellular ROS generation (data not shown). Analysis of the intracellular ROS level revealed that pretreatment with the Kefir extract kept cells to a more reductive state than control cells, even after UVCirradiation. The thymine dimer formation in HMV-1 cells pretreated with the Kefir extract was also notably reduced, compared with the control, $5 \mathrm{~h}$ after UVirradiation (Figure 6c). The apoptosis of HMV-1 cells pretreated with the Kefir extract was also suppressed, compared to the control, $5 \mathrm{~h}$ after UVC-irradiation (Figure 6d).

\section{Discussion}

Since UVC has high energy, it increases the intracellular ROS level and causes oxidative base damage in DNA like the formation of 8-OH guanin (Dobson et al., 2000). Furthermore, UVC directly produces photoproducts like cyclobutanepyrimidine dimmers and (6-4) photoproducts and inhibits DNA and
RNA synthesis (Petitfrere et al., 1996; Perdiz et al., 2000). This DNA damage results in apoptosis. Apoptotic cells exhibit morphological changes. Actually, UVC-irradiated human cultured cells exhibited morphological changes, remarkable elevation of intracellular ROS, an increase of UDS, an increase of thymine dimmer, an increased number of apoptotic cells and a decrease in colony formation ability. The Kefir aqueous extract which was added after UVC irradiation suppressed the morphological changes in human melanoma HMV-1 and SK-MEL cells and human normal fibroblast TIG-1 cells, suggesting that the Kefir aqueous extract contained active substances which could suppress apoptosis by UVC irradiation, irrespective of cell type.

UVC-irradiated HMV-1 cells exhibited an extremely high level of intracellular ROS which was maintained even $10 \mathrm{~min}$ after UVC irradiation. This meant that the cells were continuously exposed to a high risk of oxidative stress, mainly by accumulated intracellular $\mathrm{H}_{2} \mathrm{O}_{2}$, even after UVC irradiation. However, the addition of the Kefir extract after UVC irradiation resulted in a rapid decrease in intracellular ROS level. The UVC-irradiated cells recovered to as low an intracellular level as the non UVC-irradiated cells, $10 \mathrm{~min}$ after UVC irradiation. These results suggest several mechanisms, one of which is that the Kefir components directly scavenged intracellular ROS after incorporation into cells or on the outside of the cells. Another possible mechanism is that the Kefir extract stimulates the ROS scavenging enzymes such as superoxide dismutase and catalyse. Although Kefir contains strong antioxidants effective in vivo, the chemical structures of the antioxidants in Kefir have 
(a)

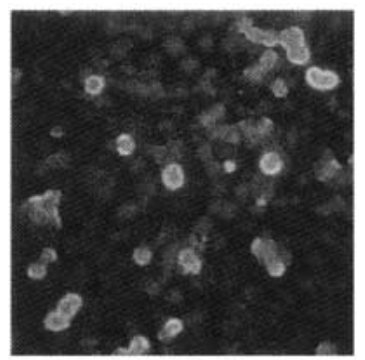

\section{Control}

(b)

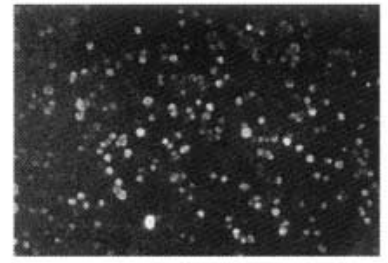

Control

(c)

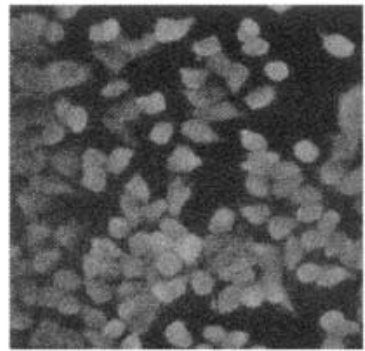

Control

(d)

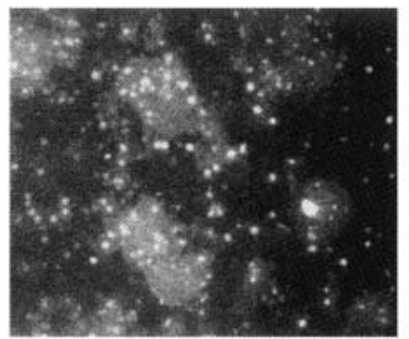

Control

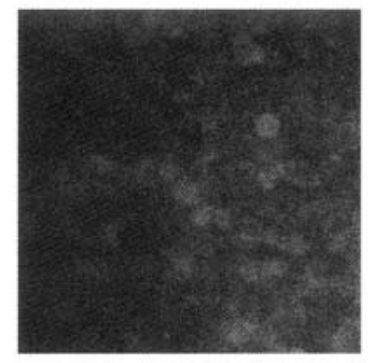

Kefir

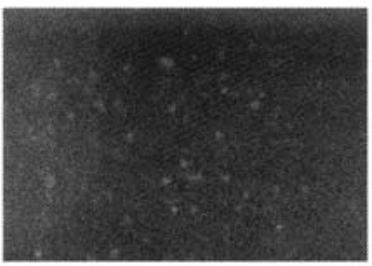

Kefir

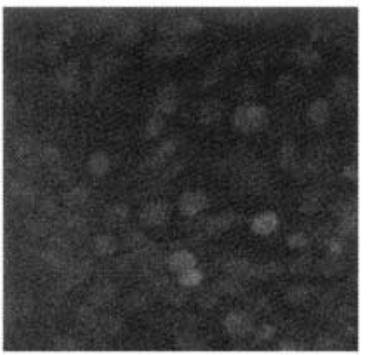

Kefir

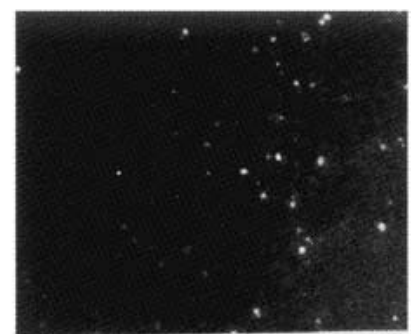

Kefir

Figure 6. Suppression of UVC damage to HMV-1 cells by the addition of the Kefir extract during or before UVC irradiation. (a) and (b): HMV-1 cells $\left(2.0 \times 10^{5}\right.$ cells) were UVC-irradiated with $60 \mathrm{~J} \mathrm{~m}^{-2}$ in the absence or presence of the Kefir extract $\left(9.6 \mathrm{mg} \mathrm{ml}{ }^{-1}\right)$. Cells were washed to remove the Kefir extract and then cultured for $5 \mathrm{~h}$. Thymine dimmers (a) and apoptotic cells (b) were detected using an immunoblot assay. (c) and (d): HMV-1 cells $\left(2.0 \times 10^{5}\right.$ cells) were pretreated with the Kefir extract $\left(9.6 \mathrm{mg} \mathrm{ml}^{-1}\right)$. Cells were washed to remove the Kefir extract, UVC-irradiated with $60 \mathrm{~J} \mathrm{~m}^{-2}$, and then cultured for $5 \mathrm{~h}$. Thymine dimmers (c) and apoptotic cells (d) were detected using an immunoblot assay. All experiments were triplicated independently and a representative is shown. 
not been reported (Kubow and Fotouhinia, 2001). The antioxidants in the Kefir extract may be grouped into desmutagens in foods, because they can scavenge ROS as mutagens before ROS damage DNA.

UV-irradiated cells exhibited elevated levels of UDS because the DNA repair systems were activated (Dell'Orco and Anderson, 1981; Ceaver et al., 1999). In addition to the rapid scavenging effect of intracellular ROS, the Kefir extract elevated the UDS level of UVC-irradiated HMV-1 cells, suggesting that the Kefir extract contained DNA repair-enhancing substances. In fact, the Kefir extract stimulated the thymine dimmer excision repair activity, suppressed the apoptosis of UVC-irradiated cells and increased the colony formation ratio of the UVC-irradiated cells. These results suggest that the Kefir extract activates the DNA repair systems and DNA damage in the UVC-irradiated cells is repaired to the extend to which cells can pass through the p53 DNA check point without triggering apoptosis. The DNA repairenhancing substances in the Kefir may be grouped into bio-antimutagens in foods, because they can reduce mutation by enhancing the DNA-repair activity.

DNA repair-enhancing substances will be effective for the prevention of cancer and other many diseases. However, only a few substances have so far been reported to have this DNA repair-enhancing ability. Many antioxidants have only the ROS-scavenging ability and not the DNA repair-enhancing ability. MMTS found in cauliflower directly or indirectly activated the NER by modulating the SH enzyme activities (Nakamura et al., 1996, 1997, 1998). Epigallocatechin suppresses UVC-induced mutagenesis of $E$. coli based on the promotion of the excision repair system (Shimoi et al., 1986). Gallocatechin activates the DNA repair activity by suppressing the cell cycle irrespective of its antioxidant activity (Matsuo et al., 1994). Emodin, which is contained in aloe and $R$. japonicus Houtt, a plant indigenous to Okinawa, enhances the NER of UV- and cisplatin-induced DNA damage in human cells (Chang et al., 1999) Emodin up-regulates the expression of ERCC1 among the NER complex and increases calcium influx.

The Kefir extract exhibited a strong thymine dimmer excision repair-enhancing activity as well as MMTS (Table 1). Epigallocatechin exhibited a weak activity but not vitamins $\mathrm{A}, \mathrm{C}, \mathrm{E}$, and $\mathrm{K}$ or catechin. These antioxidants can suppress UV-induced cell damage by scavenging intracellular ROS (Blume and Teichmueller, 1999). These results suggested that the DNA repair-enhancing activity is not related to the antioxidant activity. It is suggested that the DNA repair-enhancing substances in the Kefir extract have a molecular weight of less than 5000 and are stable against autoclaving.

By the addition of the Kefir extract only for $1 \mathrm{~min}$ during UVC irradiation, elevation of intracellular ROS level, the formation of thymine dimmer and apoptosis were remarkably suppressed (Figures 6a and b). Since the Kefir extract exhibited UV absorption, especially at $280 \mathrm{~nm}$, it is suggested that the Kefir extract might protect the cells from UV damage by cutting off UV. The application of Kefir to cosmetics is anticipated.

Furthermore, the pretreatment of HMV-1 cells with the Kefir extract for $5 \mathrm{~h}$ before UVC irradiation was also effective in preventing the elevation of intracellular ROS level, the formation of thymine dimmer, and apoptotic cell death (Figures $6 \mathrm{~d}$ and d). These results suggest that the active substances in the Kefir extract incorporated into the cells or adhering to the cell membrane before UVC irradiation, may protect the cells from UV damage by suppressing the generation of ROS and enhancing the DNA repair systems. Mice orally administrated the Kefir extract for 12 days before X-ray irradiation at dosages of 0.5 and $1 \mathrm{~Gy}$ exhibited significantly suppressed apoptosis of colon cells, suggesting that the Kefir extract had a radioprotective effect (Matsuu et al., 2001).

Purification of antioxidants and DNA repairenhancing substances in the Kefir extract is ongoing. Identification of those substances will be beneficial for developing new foods with the physiological function of preventing UV damage, irradiation damage and many diseases like cancer.

\section{References}

Amundson SA, Myers TG, Fornace AJ (1998) Roles for p53 in growth arrest and apoptosis: Putting on the brakes after genotoxic stress. Oncogene 17: 3271-3276.

Anna T, Jeno M and Matyas GJ (1994) Monitoring of benzeneexposed workers for genotoxic effects of benzene:improvedworking-condition-related decrease in the frequencies of chromosomal aberrations in peripheral blood. Mutat Res 304: 159165.

Blume G and Teichmueller EE (1999) Liposomes with anti-oxidants and their protective efficacy against UV-irradiation. SOFW J 125: 12-14.

Ceaver JE, Afzal V, Feeney L, McDowell M, Sadinski W, Volpe JPG, Bush DB, Coleman DM, Ziffer DW, Yu Y, Nagasawa $\mathrm{H}$ and Little JB (1999) Increased ultraviolet sensitivity and chromosomal instability related to p53 function in xeroderma pigmentosum variant. Cancer Res 59: 1102-1108.

Chang L-C, Sheu, H-M, Huang Y-S, Tsai T-R and Kuo K-W (1999) A novel function of emodin: Enhancement of the nucleotide 
excision repair of UV- and cisplatin-induced DNA damage in human cells. Biochem Pharmacol 58: 49-57.

Cleaver JE and Crowley E (2002) UV damage, DNA repair and skin carcinogenesis. Front Biosci 7: D1024-D1043.

Dell'Orco RT and Anderson LE (1981) Unscheduled DNA synthesis in human diploid cells of different donor ages. Cell Biol Int Rep 5: 359-364.

Dobson AW, Xu Y, Kelly MR, LeDoux SP and Willson GL (2000) Enhanced mitochondrial DNA repair and cellular survival after oxidative stress by targeting the human 8-oxoguanine glycosylase repair enzyme to mitochondria. J Biol Chem 275: 37518-37523.

Fu YC, Jin XP, Wei SM, Lin HF and Kacew S (2000) Ultraviolet radiation and reactive oxygen generation as inducers of keratinocyte apoptosis: Protective role of tea polyphenols. J Toxicol Environ Health Part A 61: 177-188.

Garcia MXU, Foote C, Van Es S, Devreotes PN, Alexander S and Alexander H (2000) Differential developmental expression and cell type specificity of Dictyostelium catalases and their response to oxidative stress and UV-light. Biochim Biophys Acta-Gene Struct Expres 1492: 295-310.

Gavrieli Y, Sherman Y and Ben-Sasson SA (1992) Identification of programmed cell death in situ via specific labeling of nuclear DNA fragmentation. J Cell Biol 119: 493-501.

Heo MY, Kim SH, Yang HE, Lee SH, Jo BK and Kim HP (2001) Protection against ultraviolet B- and C-induced DNA damage and skin carcinogenesis by the flowers of Prunus persica extract. Mutat Res - Genet Toxicol Environ Mutagen 496 SI: 47-59.

Kabayama S, Osada K, Tachibana H, Katakura Y and Shirahata S (1997) Enhancing effects of food components on the production of interferon beta from animal cells suppressed by stress hormones. Cytotechnology 23: 119-125.

Kada T and Shimoi K (1987) Desmutagens and bio-antimutagens Their modes of action. Bioessays 7: 113-116.

Kasten U, Beyersmann D, Dahm-Daphi J and Hartwig A (1995) Sensitive nonradioactive detection of UV-induced cyclobutane pyrimidine dimers in intact mammalian cells. Mutat Res 336: $143-152$.

Kasten U, Mullenders LH and Hartwig A (1997) Cobat(II) inhibits the incision and the polymerization step of nucleotide excision repair in human fibroblasts. Mutat Res 383: 81-89.

Koji T and Nakane PK (1990) Localization in situ of specific mRNA using thymine-thymine dimerized DNA probes. Sensitive and reliable non-radioactive in situ hybridization. Acta Pathol JPN 40: 783-807.

Kubo M, Odani T, Nakamura S, Tokumaru S and Matsuda H (1992) Pharmacological study on Kefir - A fermented milk product in Caucasus. I. On antitumor activity (1). Yakugaku Zasshi 112: 489-495.

Kubow S and Fotouhinia M (2001) Kefir as a potent antioxidant composition. PCT Int Appl (pp. 15), Coden: PIXXD2 WO 0197820 A2 20011227.

Matsuo T, Hanamure N, Shimoi K, Nakamura Y and Tomita I (1994) Identification of (+)-gallocatechin as a bio-antimutagenic compound in Psidium guava leaves. Phytochem 36: 1027-1029.

Matsuu M, Shichijo K, Wen C-Y, Nakashima M, Ito M, Shirahata S, Tokumaru S and Sekine I (2001) The protective effect of fermented milk Kefir on acute radiation injury in rat colon. Ulcer Res 28: 147-149.

Mitra S, Boldogh I, Izumi T and Hazra TK (2001) Complexities of the DNA base excision repair pathway for repair of oxidative DNA damage. Environ Mol Mutagen 38: 180-190.

Murofushi M, Mizuguchi J, Aibara K and Matuhashi T (1986) Immunopotentiative effect of polysaccharide from Kefir grain,
KGF-C, administered orally in mice. Immunopharmacol 12: 29-35.

Nakamura YK, Kawai K, Furukawa H, Matsuo T, Shimoi K, Tomita I and Nakamura Y (1997) Suppressing effects of S-methyl methanethiosulfonate and diphenyl disulfide on mitomycin Cinduced somatic mutation and recombination in Drosophila melanogaster and micronuclei in mice. Mut Res 385: 41-46.

Nakamura YK, Matsuo T, Shimoi K, Nakamura Y and Tomita I (1996) S-methyl methanethiosulfonate, bio-antimutagen in homogenates of Cruciferae and Liliaceae vegetables. Biosci Biotechnol Biochem 60: 1439-1443.

Nakamura Y, Nakamura YK, Tashiro S, Mukai K, Matsuo T and Tomita I (1998) Modification of enzyme sulfhydryl groups suppresses UV-induced mutagenesis depending on the nucleotide excision repair system in Escherichia coli B/rWP2. Mutat Res 407: 47-53

Nyaga SG and Lloyd RS (2000) Two glycosylase/abasic lyases from Neisseria mucosa that initiate DNA repair at sites of UV-induced photoproducts. J Biol Chem 275: 23569-23576.

Osada K, Nagira K, Teruya K, Tachibana H, Shirahata S and Murakami H (1993-1994) Enhancement of interferon- $\beta$ production with sphingomyelin from fermented milk. Biotherapy 7 : 115-123.

Perdiz D, Grof P, Mezzina M, Nikaido O, Moustacchi E and Sage E (2000) Distribution and repair of bipyrimidine photoproducts in solar UV-irradiated mammalian cells - Possible role of Dewar photoproducts in solar mutagenesis. J Biol Chem 275: 2673226742.

Petitfrere C, Clingen PH, Arlett CF and Green MHL (1996) Inhibition of RNA and DNA synthesis in UV-irradiated normal human fibroblasts is correlated with pyrimidine (6-4) pyrimidone photopruduct formation. Mut Res - Fund Mol Mech Mutagen 354: 87-94.

Pool-Zobel BL, Munzer R and Holzapfel WH (1993) Antigenotoxic properties of lactic acid bacteria in the $S$. typhimurium mutagenicityassay. Nutr Cancer 20: 261-270.

Ravanat JL, Douki T and Cadet J (2001) Direct and indirect effects of UV radiation on DNA and its components. J Photochem Photobiol B - Biol 63: 88-102.

Razzaque MS, Koji T, Kawano H, Harada T, Nakane PK and Taguchi T (1994) Glomerular expression of type III and type IV collagens in benign nephrosclerosis: Immunohistochemical and in situ hybridization study. Pathol Res Pract 190: 493-499.

Rhodes CJ, Dintinger TC, Moynihan HA and Reid ID (2000) Radiolabelling studies of free radical reactions using muonium (the second hydrogen radioisotope): Evidence of a direct antioxidant role for vitamin $\mathrm{K}$ in repair of oxidative damage to lipids. Mag Res Chem 38: 646-649.

Sancar A (1996) DNA excision repair. Ann Rev Biochem 65: 43-81.

Shen HM, Shi CY, Shen Y and Ong CN (1996) Detection of elevated reactive oxygen speies level in cultured rat hepatocytes treated with aflatoxin $\mathrm{B}_{1}$. Free Radical Biol and Med 21: 139-146.

Shiomi M, Sasaki K, Murofushi M and Aibara K (1982) Antitumor activity in mice of orally administered polysaccharide from Kefir grain. Jap J Med Sci Biol 35: 75-80.

Shimoi K, Nakamura Y, Taomita I, Hara Y and Kada T (1986) The pyrogallol related compounds reduce UV-induced mutations in Escherichia coli B/r WP2. Mutat Res 173: 239-244.

Teruya K, Yamashita M, Tominaga R, Nagira T, Katakura Y, Tokumaru S, Barnes D and Shirahata S (2002) Fermented milk Kefram-Kefir enhances glucose uptake into insulin-responsive cells. Cytochnology 40: 107-116.

Thoreux K and Schmucker DL (2001) Kefir milk enhances intestinal immunity in young but not old rats. J Nut 131: 807-812. 
Venema J, Van Hoffen A, Karcagi V, Natarajan AT, Van Zeeland AA and Mullenders LH (1991) Xeroderma pigmentosum complementation group $\mathrm{C}$ cells remove pyrimidine dimers selectively from the transcribed strand of active genes. Mol Cell Biol 11: 4128-34.

Vervoort LMT, Ronden JE and Thissen HHW (1997) The potent antioxidant activity of the vitamin $\mathrm{K}$ cycle in microsomal lipid peroxidation. Biochem Pharm 54: 871-876.

Wiseman H and Halliwell B (1996) Damage to DNA by reactive oxygen and nitrogen species; role in inflammatory disease and progression to cancer. Biochem J 313: 17-29.
You YH, Lee DH, Yoon JH, Nakajima S, Yasui A and Pfeifer GP (2001) Cyclobutane pyrimidine dimers are responsible for the vast majority of mutations induced by UVB irradiation in mammalian cells. J Biol Chem 276: 44688-44694.

Zubillaga M, Weill R, Postaire E, Goldman C, Caro R and Boccio J (2001) Effect of probiotics and functional foods and their use in different diseases. Nut Res 21: 569-579. 